\title{
Discipline in the Light of Alternative Ways of Educating Learners
}

\author{
Bogusław Śliwerski
}

University of Łódź

Received $30^{\text {th }}$ May 2018/ final version received $10^{\text {th }}$ September 2018/

$/$ accepted $12^{\text {th }}$ September 2018

\begin{abstract}
The article presents an analysis of the concept of discipline in alternative schools throughout the world. The issue of school discipline has given rise to a dispute within the field of pedagogy about the place and role of discipline in school education, as there are many misunderstandings, contradictions, and myths surrounding this issue. In bringing up this topic, the matter is often dealt with in a fragmentary or onesided way, depending on who is a representative of a particular ideology of education, i.e., whether or not he or she is a supporter or an opponent of disciplining students in the school. This article explores the question of whether or not a difference exists between the assumptions and practices of education in public and alternative schools. I suggest looking at models of (non-)discipline in school education due to acceptance or lack of it by teachers. I maintain that in a global world of interconnected meanings, theories, models, experiences, and individual educational solutions alternative schools stop being different from some public schools.
\end{abstract}

Keywords: alternative education, pedagogy, school, discipline, ideology of education, freedom and harsh upbringing

An underlying principle of an open and pluralistic society is voluntariness. What has emerged from modernism is the new epoch which is deprived of distance, universal projects, social utopias, stability and unambiguity, and which does not thoughtlessly affirm the status quo in daily life, social theories and concepts, or systems of orientation. What is recognized in this epoch is the right to different forms of knowledge, lifestyles or behaviour patterns. Nevertheless, adults' authority is still binding - they decide about the educational process and the norms within educational institutions, but while taking learners' opinions into consideration.

Therefore, what becomes the decisive criterion determining a person's attitude to social norms is the way in which they are perceived and in which 
pluralism and democracy are recognized, as well as the way of handling them. If people view these states as a necessary evil which cannot be withdrawn from, they try to derail it or to oppose it actively. Postmodernism necessitates the perception of the daily world of life and its phenomena from different angles, owing to which they can appear to every subject of the educational process quite differently but maintaining their own sense (Śliwerski, 1998). Being a part of a democratic society, of the pluralism of its cultures, values, systems of orientation and organizational structures, an educator experiences the right to various behaviours, tendencies and identifications and is guided by a variety of interests and values. On the other hand, the same educator gets into conflict with this multitude and the criteria, which often contradict their own views or standpoints, and becomes aware of the difficulty or even failure in reaching consensus or reconciliation.

Therefore, it is necessary for pedagogy to return to scientific debates on the place and role of discipline in school education due to many misunderstandings, contradictions and myths concerning it. In educational sciences, this issue is undertaken in a fragmentary or one-sided way, depending on the educational ideology in which the supporter or opponent of disciplining school learners believes. This seems to be triggered by occasional incidents including violence and appalling public opinion in schools worldwide - the events of which the actors are either a learner or a teacher who uses violence towards another person. What seems a natural response to such situations is raising the issue of discipline, or rather of its lack - in the cases when someone dares to infringe on the personal liberty and/or dignity of someone else. The crucial question is whether there is any difference in this respect between the educational assumptions and practices in state and alternative schools. Whereas education in state schools in democratic countries is subordinated to the dominating ideology of the educational authorities, the alternative school system - due to its independence from state control - may represent a variety of pedagogical approaches to educating learners at school.

Undertaking the issue of discipline in the education of the young, as one of the basic theoretical and practical categories in school education so far, has resulted from a renaissance of studies and analyses in different countries, which have recently made their way into scientific literature. This revival in research has been subjected to cognitive re-exploration by Stanislav Bendl from the Czech Republic (Bendl, 1998, 2001, 2003, 2004a, 2004b, 
2004c, 2005). In Poland, the scientific discourse on discipline at school is nothing new. It was raised in the 1920s and has returned from time to time to appear allegedly as both novelty and the necessity to solve the problem of learners' discipline at school.

Pedagogical ideas do not get ordered in a row with time along the line of progress, older ideas are not suppressed or absorbed by newer ones but they maintain their irreplaceable value. For these or other reasons, in some historical periods, certain ideas die out to come back to life with a new strength in others - in different formulations and contexts. (Szymański, 1992, p. 5)

As a result of its criticism, neoliberalism has been strictly subordinated anew to educational ideologies and to politicians, for whom the problems of violating social norms of behaviour by a marginal (in the scale of the whole country) percentage of learners become an occasion to fulfil the aims of the ruling party or its opposition (Witkowski, 2009; Śliwerski, 2009). However, a few educationalists in Poland undertook the issue of discipline as an educational method in the period of liberating science from state censorship, regardless of all the state determinants (Mieszalski, 1997; Muszyńska, 1997; Pyżalski, 2007; Surzykiewicz, 2000). Translations into Polish of pedagogical literature coming from other countries strengthen the orientation towards the prevention of, intervention and research into what is broadly termed

school violence. This enhances the perception and understanding of the scale of this phenomenon in a much broader sociocultural and political context (Robertson, 1998; Zarzour, 2006; Edwards, 2006), as well as increasing the need for restoring in schools the socio-moral order, mostly through discipline.

\section{Discipline as a Pedagogical Category}

Discipline is approached in pedagogical theories either as a way or means of moral education aimed at subordinating learners to the binding norms and authority (Latin disčpplinna - upbringing, raising, exercising) or as an educational aim (Latin disč̆plīna - order). In the 1930s, Bogdan Nawroczyński wrote that the person who does not understand at least two very simple and clear truths that: "(1) in every moral education there are moments of freedom and obligation, (2) there are very many, often contradictory, types of freedom and obligation in education" (Nawroczyński, 1987, p. 279), uses a disabled abridgement of contemporary pedagogical thought. Such a person thinks that there is only one type of freedom in education - so-called negative 
freedom, the liberation from any obligation, limitation, necessity (barbarian chaos, anarchy) and one type of compulsion - negative obligation, mechanical training, physical oppression, maltreatment of learners or their instrumental abuse for other goals. Supporters of authoritarian education ignore the knowledge concerning both the so-called positive freedom (referring to learners' conscience as the agency which evaluates learners' behaviour, taking into account social, religious, moral values by learners in their activity, following the motives which originate from the deepest held beliefs and self-control) and positive obligation, resulting from environmental and logical necessities.

It is impossible to find total freedom or total dependence in any society, hence - any school. Both categories are only the imagined poles between which real-life situations take place and oscillate.

All social institutions are, after all, based on the use of coercive means, or on the assumption that the individual is not able to make "good choices" "good" in the sense of both "the individual's good", "social good", and both at the same time). Treating the individual as basically untrustworthy exactly results from the saturation of ordinary life with the violence of institutions which lay claims to the right to be the only authority empowered to establish the standards of good conduct. (Bauman, 1996, p. 40)

Thus, if children are to learn what is necessary for life and for practicing a particular profession in their future life, their education must be neither a free game of powers nor freely applied violence. "Learning can be neither fun nor pleasure; it has to be an unpleasant, externally imposed duty" (Nawroczyński, 1932, p. 13).

There is no school system which would abandon all forms of coercion towards children. Yet, discipline can have a positive dimension if the teacher shows love to children and respects their dignity, trying to convince them to the desired behaviours, establishing and executing from them requirements without physical or mental violence. Janusz Korczak wrote the following about this:

School creates a rhythm of hours, days and years. School clerks are to fulfil the current needs of young citizens. The child is a rational being, knows well the needs, difficulties and obstacles of life. Neither a despotic order, nor imposed rigours and untrustworthy control, but tactful agreement, the belief in experience, collaboration and coexistence. (Korczak, 1984, p. 76) 
According to British sociologist Anthony Giddens, the contemporary world is no longer easily subordinated to the rigorous rule of man over other people or the environment of their life and development. It has become a world of dislocation, the "escaping" world, the world of generated uncertainty. This uncertainty has broken into daily life, changing both the sources and ranges of risk. People must engage with the broader world in order to survive in it. This occurs with the broadening of their social reflectivity as an effect of the necessity to receive and filter by individuals a lot of information which is significant in their life situation. Thus, increased social reflectivity might become the main factor disturbing the relations between knowledge and power. In a world full of the "heuristics of fear", generating a situation of collective threat which humanity has created itself, responsibility is not a duty. It implicates "tedious deciphering of reasons, not blind obedience. It rises against fanaticism but has its own driving force, because freely undertaken obligations often have bigger binding power than those imposed in the traditional way" (Giddens, 2001, p. 30).

The transition of post-socialist societies from a totalitarian to a democratic political system must have led to the stage of moral anomy, in which the norms binding in the previous period ceased to be valid and the new still had not gained recognition as a result of weakened processes of social control. Some people began identifying democracy with unlimited freedom, devoid of responsibility and any obligation, hence - without experiencing negative sanctions. The inflation of liberalism in various doctrines, ideas, theories or concepts permeated to all social and humanistic sciences, as well as to different fields of social, economic and political life. Jan Sokol describes this brand of liberalism as a gangster liberalism, best characterized by the following mottos: "grab for yourself as much as you can; money does not stink; do not look at others; there is nothing that can be called common interest" (quoted in Bendl, 2001, p. 26).

Discipline is the thing the lack of which is most strongly felt in social reactions. What has taken place in the present era is a decline in morality, discipline and the sense of duty, as well as an increase in anarchy and intolerance. This results in disobedience among youth, growing aggression and brutality in children's behaviour, attacks of vandalism and the use of drugs. (Bendl, 2001, p. 9)

According to this Czech educationalist, in schools, there is a spirit of disobedience, the growing indifference of the environment to learners' 
vulgarisms, impudence, brutalization of their behaviour and persecution of others. As some representative studies conducted among Czech teachers (by a research team from Charles University in Prague) show, 45\% of teachers would willingly resign from their activity in this profession due to the constantly worsening behaviour of learners (ibid., p. 11). In the Czech Republic - as early as 1995, the Minister of Education, Youth and Sport issued a directive on counteracting signs of racism, intolerance, and xenophobia.

In Poland, after some events in Polish schools which shocked public opinion in the 2000s, Lech Witkowski noted that the sporadic, but extreme in their effects, acts demonstrating learners' disdain towards teachers or of experiencing violence in mutual relations by learners and/or teachers, proved the lack of normality in the daily life of school.

$\mathrm{w}_{\mathrm{e}}$ are still the hostages of the lack of understanding and implementation of what [...] teachers should be taught not to expose themselves and youth to such dramatic threats, pathologies and perversions, which question the sense of treating school as an institution that still can something, in the conditions of increased interactive difficulties with learners. We still have no antidote to the potential of barbarism at school, legitimized by the school itself and its blindness to its own incapacity and the mechanisms which perpetuate it in the mode of functioning of the fictitious collective (called pedagogical) body, in which teachers are only a minority. Without the pedagogical body, the spirit of the school is dying out. (Witkowski, 2009, p. 13)

Thus, how is it with teachers' disciplining the learners in state and alternative schools? Are there any differences in the approach to applying this educational method in both types of schools?

\section{The Cartography of Alternative Education in the Context of Freedom and Obligation}

What is suggested here are the models of (non-)existence of discipline in moral education at school, due to its acceptance or not by teachers. In a global world of the diffusing senses, theories, models, experiences and individual educational solutions, alternative schools basically cease to differ from some state schools. This takes place as some teachers travel a lot over the world, establish contacts with colleagues from other countries within the Erasmus+ programme, study pedagogical literature or undertake various forms of professional development. The pedagogical boundaries between private 
and state schools are disappearing, because with growing frequency what takes place in both types of school does not differ much, apart from the fact that private school is paid though tuition. Private schools have smaller class sizes and a slightly more diversified curriculum than state schools. However, the methods of working with children and youth, methods of disciplining them based on authority, punishing and rewarding, or the disciplining which refers to learners' intrinsic motivation and their developing interest in knowledge can be found in every school. It is not discipline which is a pedagogical problem, as is presented in various scientific treatises, but the differentiation in anthropological attitudes of teachers and the designers of their professional roles towards children. For centuries, at least several philosophical foundations of education have been clashing: the perennial, naturalist (humanistic), pragmatic and post-humanistic.

Table 1

Four Models of Education Depending on the Relationship between Learners' Freedom and Disciple

\begin{tabular}{|c|c|c|c|}
\hline & & \multicolumn{2}{|l|}{ A disciplining teacher } \\
\hline & & yes & no \\
\hline \multirow{2}{*}{ 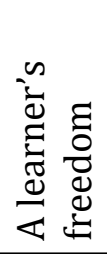 } & yes & $\begin{array}{l}\text { democratic schools, } \\
\text { anti-authoritarian schools, } \\
\text { duality of freedom and obligation }\end{array}$ & $\begin{array}{l}\text { schools of stress-free education, } \\
\text { positive obligation, } \\
\text { schools of freedom }\end{array}$ \\
\hline & no & $\begin{array}{l}\text { authoritarian schools, } \\
\text { negative obligation }\end{array}$ & $\begin{array}{l}\text { self-education, } \\
\text { self-learning, self-socialization }\end{array}$ \\
\hline
\end{tabular}

Source: elaborated by the author

\section{Discipline in Authoritarian Education}

Authoritarian education is relatively strongly associated with realistic and Thomistic philosophy, in the light of which the human is a thinking being and school, as a social institution, is created to help children and youth to develop their intellectual and spiritual potentialities. However, this necessitates molding the individual into obedience, which seems to be achieved best by authoritarian schools, in which discipline is either the means or aim of education. The role of moral education is to exercise learners in their obedience. In the public, widely accessible school system, discipline understood in this way determines executing autocratic educational rule 
over a learner or a class (Sławiński, 1994). Such discipline explicitly defines relations between learners and comprises a set of tools and techniques for behaviourally punishing or rewarding them. The essence of disciplining learners is leading them into the state of order and obedience, forcing them into desired behaviours, triggering their unceasing readiness to self-control, and working out (in the learners) the indispensable habits to achieve this. In such an approach, a learner is treated as an object, which can be formed, trained, kept in control, subjected to regime and drill, owing to the previously planned coercion towards them by enforcing their self-discipline and selfcontrol (Kosiorek, 2007; Bendl, 2004a).

The authoritarian orientation takes place in the schools in which teachers do notaccept learners' rights to the freedom of learning and their participation in this process. Therefore, these teachers use all means and methods of disciplining learners, steering their developmental process (punishing and/ or rewarding) externally. If teachers' culture is authoritarian, regardless of the scientific advancement of school didactics and psychology of education, they will apply formal discipline, punish for mistakes or bad behaviour and reward success and a high level of obedience. Such education is practiced in some military and religious schools, as well as in schools subordinated to the conservative moral education of the young in absolute respect for outer, formal authorities of the ruling power and institutions.

In the authoritarian school, there are individuals possessing power (head-teachers, teachers, administration) and people subjected to this power (certain teachers, learners, parents, and administration workers). This category of power is associated with the phenomenon of disciplining others and exacting obedience from them, because power assumes the existence of the subordinated party in compliance with the principle that there is no lord without a slave. Therefore, education becomes the transforming of the "educational material" towards the indicated educational ideal of discipline and obedience. What occurs here is the phenomenon of educational totalism, because - consciously or not, openly or in disguise - educators aim at giving themselves the exclusive right to making themselves the model for learners or at adjusting learners to the desired educational pattern. Such an educator believes neither in a young person's freedom nor in the existence of ethical values and their attractive character. They are not significant, what is important is everything that allows the overpowering from a young person's mental and physical development from outside (from the perspective of 
ideology, politics, models or theories). Thus, the educator is left only with the possibility of applying rigorous training and shaping the learners in different ways.

Although the world of school education is undergoing changes, in the majority of schools, teachers refer to the need of increasing - in the directive, ordering-banning way - discipline in learners' education in order to provide them and their teachers with appropriate conditions for the well-focused process of learning and teaching. In these institutions, the concept of active inclusion of learners into the process of socio-moral self-education is still treated with unwillingness. It is assumed that the discipline concerning social norms should be demanded from learners to such an extent that it can fulfil the following functions: the indicative (making learners aware of what they should know, how they should behave and what they can expect from others), the protective (ensuring individuals' feeling of safety owing to right laws and following them by all), the socializing (discipline is the sine qua non of normal functioning of a particular community), the optimizing (increasing the effectiveness of human activities) and the existential (enabling the survival of humanity) (Bendl, 2004a, s. 29).

Children's school experience of physical and/or mental violence or of teachers' hostile attitudes to them results in the reproduction of the syndrome of an abused child - when they become adults, they reproduce the same conduct towards others. Science calls this style of education "black pedagogy", which enlarges in the society the area of pedagogical evil, violence, humiliation, and perpetuates the consent for this way of enslaving children. Pedagogy understood in this way is black, vicious, cruel and evil because it is based on a strong belief in the necessity to bring up children in humbleness and absolute submission to adults, who are entitled to use violence towards them for their good. With growing frequency, physical violence is underlies mental violence in such spheres as: intellectual violence ("brainwashing", "indoctrination", "persuasion") or volitional violence (enforcing selfperfecting, self-control, self-suppression). If the duty of children and youth to show respect to their teachers, regardless of the reasons which go along their conduct, is added to this, the scale of learners' enslavement and vulnerability becomes enlarged (Sławiński, 1994).

What seems to be binding in schools is the idea of proletarian democracy - accumulating by particular subjects (by head-teachers towards teachers 
and teachers towards learners and their parents) the monopoly for the truth with the power of instruments of violence (negative selection of learners, restrictions on disobedient teachers, isolationism towards parents who are excessively interested in the real causes of evil at school). In Polish schools, there are head-teachers and teachers who deeply oppose the above-discussed principle of social order. Not accepting democracy, they regret that they have to implement its principles and activate certain mechanisms in school life. They take part in passive resistance towards it with impunity or they practice open or secret sabotage (Śliwerski, 1996).

In an authoritarian society, only authoritarian personalities can be educated, which was often indicated by Janusz Korczak - e.g., "We cannot change our adult life as we are ourselves brought up in slavery, we cannot give freedom to a child as long as we are in handcuffs ourselves" (Korczak, 1984, p. 187). State school, understood in this way and constantly reproduced, is still to be an institution in which obedience is obligatory of parents towards teachers, "small" learners towards "great" teachers, the weaker towards the stronger, the subordinates to their supervisors. However, discipline in this sense - as a way or means of education, raises a debate among educationalists concerning its negative effects, which result both from the authoritarian way of shaping children (with special emphasis on the representatives of black pedagogy) (Miller, 1991, 1995, 1999, 2000, 2006) and from the permissive and liberal approach to socially unwanted behaviours of the young (Gutek, 2003). There is universal consensus that discipline in some form should be one of the aims of education which consists in children's appreciation of organization, order, exercising the mind and the character, collaboration and behaviour compliant with the socially binding rules and norms - as long as this aim is treated as heterotelic. A contemporary attempt to bring together the need or necessity of subjecting children to certain limitations and their right to dignity and self-determination is provided by Thomas Gordon in his concept of failure-less (win-win) education, which paves its way in the school reality with difficulty (Gordon, 1991, 1995, 1997).

The post-totalitarian, hierarchical, centralistically governed system of school education has consolidated not only the model of authoritarian management of educational institutions but also their formal-organizational nature. In such a hierarchically understood system of education in which the vertical (and diversified in territorial reach) gradation of the whole system and its 
subsystems occurs, all forms of autonomy and self-government are set up from the top down. Even if some possibilities of their grassroots existence or creation are allowed, the scope of their tasks and functions is determined by the educational authorities of the ministry. In a way very distant from the idea of democracy and self-government, educational institutions have perpetuated the belief that the mutual relations of educational authorities with head-teachers, of head-teachers with teachers, and teachers with learners and their parents have to be based on the authority of a person with a higher rank in the social hierarchy. Moreover, authority is understood here as a particular degree of obedience, discipline or subordination.

State school in Poland was to restore its normality by liberating both from the Marxist ideology and the liberal one - provided it was imposed on teachers as the only right one for the implementation of the national curriculum. In 2006, the principle was introduced in Poland (through a parliament act) of zero tolerance of violence in state schools, which was to refer to learners and teachers. The right-wing educational authorities decided to pejoratively stigmatize the educators, sociologists and psychologists:

[...] who still promote toxic myths that learners should be guided by their subjective beliefs that they will not hurt themselves, that one cannot "impose" on or even suggest anything to them. Nothing is worse for education than the myth of education through the lack of it. What binds in pedagogy, as in medicine, is the principle: first, to do no harm! If we want the young generation of Poles to be able to get a reliable education and character shaping, let us not allow for the unpunished presence in our schools of demoralizers and false prophets of easy happiness - the happiness achieved without moral rules, without alertness and discipline. "Stress-free" education is the protection of hooligans, as people with right moral education do nothing that can stress them. (Dziewiecki, 2006, p. 1)

The belief was disseminated in the public discourse that stress-free education is the most dangerous myth, based on a naïve concept of humanity, the ideology of liberal fiction and the Marxist principle of political correctness, in the light of which it is possible to educate through the lack of education and discipline.

For the past several years, "modern" educators - in recent years obvious facts have been repeating archaic myths about spontaneous self-fulfilment, and about the ideologically neutral school (even though some ideologies are criminal!) or about education without stress, hence - without suffering the consequences of learners' own acts. (Dziewiecki, 2006, p. 1) 
The Ministry of National Education introduced this programme as an answer to: (the presence in state schools of) violence among learners in their relations with teachers, to lowered learning discipline (increased numbers of learners playing truant, abandoning school or not fulfilling school obligations), drug dealing and increased use of alcohol and cigarettes, learners' prostitution, theft, vandalism, etc. In order to prevent these phenomena, the requirements were introduced of wearing school uniforms, of monitoring school space, of limiting the access to unwanted, demoralizing websites during school classes. The decision was made to replace social control, which could be conducted in educational institutions by kindergarten or school councils, with technical apparatus (cameras, one-way mirrors, identity cards, entrance turnstiles, boxes for anonymous reports, etc.).

School obedience understood in this way and "[...] based on brutal violence is a mistargeted pedagogical measure, as most frequently it triggers in young souls the rebellion against the defended order instead of raising the belief that this order has a social and moral value and should be respected" (Nawroczyński, 1932, pp. 26-27). What is forgotten in the air of demagogic debates is the fact that education is a specifically human sphere and that pedagogy (which explores, describes and explains it) is a humanistic science, not a technical one aimed at instrumental managing people as soulless robots. It might seem that the years of past totalitarianism has already made Poles sensitive to the lack of freedom, to feeling its mechanisms of dehumanization and depersonalization, to depriving people of their rights, to disregarding their will and to emotional insensitivity. Teachers written into such a reality - instead of answering the question how to love others as a part of their profession, how to help and liberate them, how to include them into life and give them a socially wanted sense - are forced to apply the attitude of professional distrust, forbidding, excluding, isolating and not loving their learners, because this poses a threat to the logic of the state.

Social engineering conducted in this way is aptly reflected upon by Stanley Fish, a critic of literary theory: win the language and you will win in politics "Words to which people react will acquire the senses attributed by you" (Fish, 2006, p. 17). No wonder that every time when the phrase "school violence" appeared in media, it is automatically associated with such categories as: stress-free education, the child's rights, lack of discipline, chaos, freedom, emancipation, child-centeredness, alternative, liberalism. The expressions 
intercepted in this way were to be associated negatively in the society, acquire a destructive character, eradicate any benefits or advantages associated with them, and were to make using them the biggest insult. Thus, it is impossible to be a teacher, patriot and liberal, as it is supposed that executing proper behaviour and education towards emancipation and moral autonomy is not feasible without referring to discipline as an educational measure.

For those who practice authoritarian educational rule in the state, the problem of violence is reduced to formalized social control (such influencing the school system so that it can develop in the desired direction) on one hand, but on the other, it legitimizes the functioning of the ruling authority as a specific ability to acquire the goal more efficiently. Aiming at hiding their real interests, the authorities reach for anti-dialogical activities - for manipulation, which is to sedate the society to take control over it more easily. If we accept Paulo Freire's position that cultural activity of the authorities serves either the ruling or liberating people, their activity based on disciplining others is directly or in a hidden way targeted at keeping within the ruling authority such solutions and views which favour the representatives of this activity. The anti-dialogical cultural invasion consists in the authorities' penetration of the cultural contexts of other political (also educational) environments, which are recognized as alien and hostile. Moreover, by ignoring their potential, the ruling authorities impose their own worldview on "the invaded", preventing their creativity and blocking their self-expression.

Thus, cultural invasion, whether polite or sharp, is always an act of violence aimed at people whose culture has become an object of invasion: these people lose their uniqueness or face the threat that they will lose it (Freire, 1973 p. 22). However, when the supporters of authoritarian education come into the leading power, the space of public discourse gets closed and the transition to the stage of permanent antagonistic war takes place - the war ultimately aimed at excluding every educational perspective which is different from the one which dominates among the authorities. Yet, where war takes place, extreme attitudes have to come into being. There is no acceptance of pedagogical ideas without winners and losers. It is not important then that this will not last too long as every domination triggers off resistance. 


\section{Discipline in Anti-authoritarian and Democratic Schools}

The democratic orientation concerns mostly alternative schools - antiauthoritarian and state schools with the organs of social grassroots control, in which teachers promote the values of democracy and self-government. In such institutions, learners' sovereignty is supplemented with the socialization within the contract with school, which concerns mutual following the principles of learning and behaving. The teachers employed in these schools support learners freedom of learning with simultaneous sustainable use of coercion towards them (barriers, limitations). The teacher is a facilitator, moderator or tutor of people who learn for themselves, not for grades, out of fear or to achieve other goals. Such teachers will do a lot to become learners' partners in fulfilling the educational curriculum and the educational contract. This takes place in the Dalton Plan schools (Popp, 1995; Rýdl, 2001; Röhner \& Wenke, 2003), Célestin Freinet's schools (Ecole Moderne; Freinet, 1991), Laboratory School (Laborschule) in Bielefeld (Thurn \& Tillmann, 1997), Glockseeschule in Hanover (van Dick, 1979), in Steiner's schools, as well as in some state schools supervised by school councils, the members of which are teachers, learners and their parents. Educators cherish dialogical relations, include learners into participation in all stages of the educational process - not only in the design and choice of contents but also in their implementation, evaluation and establishing the consecutive learning thresholds (Thurn \& Tillmann, 1997; Dietrich, 1995). In shaping socio-moral attitudes, mediation and joint recognizing and solving problems is used so that the same rules of coexistence could be binding for both teachers and learners or their parents.

For almost 120 years, pedagogical sciences have been calling for the humanization of education, for abandoning the (still convenient for some parents and teachers) "carrot and stick" model, which humiliates those who cannot defend themselves actively or passively against violence (Key, 2005; Kohl, 1971; Neill, 1969, 1975). The anti-authoritarian orientation is manifested by teachers referring to positive obligation towards learners, the teachers who respect students' sovereignty and who abandon the forms and methods of their outer disciplining, based on instrumental (behavioural) punishing and rewarding. Most frequently, this approach is called stress-free education, which indicates the focus on learners' rights to their freedom of 
learning (intrinsic, positive obligation). Extrinsic obligation is avoided in favour of learners' undertaking the mechanisms of self-guidance in their own development and in bearing the responsibility for it. For their learners, teachers treating education as the learning environment mostly based on positive stress become facilitators (Selye, 1974), tutors or even coaches, who support them in intensive self-development. Such teachers' focus on learners is aimed at excluding negative stressors from their school environment so that learners could become the authors of their own development.

What becomes the philosophical foundation of this educational model is the naturalistic approach to school character shaping, which assumes that the human nature itself is a universal system and a perfectly functioning mechanism. It develops gradually, evolutionarily, constituting the foundation of both the knowledge and character of an individual. Thus, in school education, it should not be allowed to limit a person's self-esteem (amour de soi) - the individual will move towards inborn love of life, as well as the feeling of personal dignity (amour propre), which manifests the affirmation of love. On the basis of both of them, school might implant humanistic values, enhancing in this way the agreement between a natural tendency and the will of the society so that learners could resist the temptations and urges of their own egoism and the social pressure. In such a situation, school becomes an appropriately prepared (by adults) environment, in which learners can preserve their natural qualities. At the same time, school stimulates learners to acting and making rational choices, "[...] provided they bear both their positive and negative consequences" (Gutek, 2003, p. 71).

Learners who acquire knowledge as a result of the liberty which they have been granted and the recognition of their motives, needs, interests and aspirations, can construct their own identity and the reality of daily life. "As children are born as good beings, the process of education - if it is to educate moral people - has to be adjusted to children's reactions and inclinations. The curriculum and teaching methods should enable the child their natural development" (Gutek, 2003, p. 75). In this approach, discipline becomes redundant so that individuals do not lose their primary innocence and the characteristic features of the relations with teachers are trust, authenticity, indirectness of influence, and mutual learning. True moral education takes into account natural developmental stages, preparing learners for free and adequate (to their individual character) overcoming the consecutive stages. 
Discipline might only become a derivative of the social contract reached between the teacher and learners.

This model of relations between teachers and learners is familiar from Maria Montessori's pedagogy. The educator prepares (for children and youth) an appropriate environment for individual and independent learning based on free choice. Still, this involves a certain type of compulsion which limits children's liberty in a substantial way (Nawroczyński, 1932, p. 16). What should discipline children is written into the didactic method, means and the craft of animating the learning process by the teacher, whose every wish or request addressed to children is almost immediately fulfilled with delight. This takes place because it is expressed in such a way that children are convinced they want this themselves and they can do this (Montessori, 1990). As Montessori writes, they show pride when they can discover something, because discipline is a consequence of the respect for their own work and the awareness of the others' right to the same.

It does not happen that a child would take a didactic aid (Arbeitsmaterial) from another child, even if they desired it very much - instead, they wait patiently until the aid is free; very often the child curiously observes another child working with the material which they want to acquire themselves. Thus, discipline becomes stabilized on the basis of a child's inner factors and appears suddenly when children work independently from one another, simultaneously developing their own personalities; however, this activity does not result in "moral isolation"; just the opposite - mutual respect, kindness and the feeling of interpersonal bonds appear among children without the need for practicing them. (Montessori, 1976, p. 93)

According to A. S. Neill, practically all children are poorly raised. Only a few children grow up in a family that would guarantee them freedom, the ability to create themselves and authentic expression of their own experiences and feelings without aggression towards other people. They must relieve stress and they have problems not only with their own identity, but with the world of their own feelings, too. Their parents are just as unhappy as their children. In addition, parents do not realize that in the course of education they transmit to them their hate, feelings of helplessness, complexes and a ready scenario of an oppressive way to solve interpersonal problems. 
All parents are trying to change, 'shape' the character of the child by imposing his or her own personality on the child. This type of approach is not in the child's interest. It is an idea of forming a man on his or her own image (Neill, 1975, p. 20).

Alexander Sutherland Neill's pedagogy is proof of his own thesis that freedom in upbringing is possible and behind the freedom does not have to be the desire to manipulate the child. There is only a need to change your own point of view on mutual interactions and their educational functions. The biggest barrier in reforming education is the patriarchal mentality of most parents and the strengthening of traditional models of enslaving children in education. When a child goes to school, teachers can only trust the immanent tendency of development and growth of the body and the personality of the child. Neill calls it the principle of self-regulation. This means that the child can regulate the satisfaction and reveal basic needs such as eating, sleeping, sexuality, social behavior, games, learning, etc. in every period of its life. The child should only have the opportunity and support to see and respect his or her individual and social interests.

The purpose of education is a free person, a fully happy being, who lives in harmony with adults and the older generation. In this light, discipline in the sense of external obedience is unnecessary. Education should be the development and support of the child's interests and curiosity. Thanks to it, the child can be self-fulfilling and happy. It also means enabling the child to develop his or her whole personality, originality, not only the intellectual sphere. In this sense, education is also the emancipation of a child, also from external discipline (Štrynclová, 2003; Ludwig, 1997).

Discipline in anti-authoritarian schools derives from positive freedom of learners, who are guided in this process by deep culture of self-control and intrinsic motivation, compliant with their aspirations and the self-awareness of the developmental potentialities or the own activity. "It can be rightly called the obedience of the rights imposed by the own conscience" (Nawroczyński, 1932, p. 23).

The acquisition of intellectual techniques necessary for the insight into the nature of good, truth and beauty, as well as for consolidating the principles which determine what is right and just, requires the education based on universal, timeless values in the inner and outer order in a school class thus, in discipline. Therefore, the teacher has to avoid both permissiveness and despotism in relations with learners. 
Excessive permissiveness consisting in total subordination to children's fancies results in the negation of any discipline and to anarchy. On the other hand, a teacher representing the despotic approach - who makes use of the fear of corporal or mental punishment and aims at shaping the learner according to the standard model - suppresses the learner's individualism, condemning spontaneity and creativity as unwanted deviations from the norm. (Gutek, 2003, p. 287)

The philosophy of pragmatism, dominating in the contemporary world, directs the child's education towards learning through acting, which comprises a variety of activities - from playing, through experimenting, to the own creation. School education is meant to take place in an open environment, enabling the development of thinking and the instant use of knowledge to solve different problems, without imposing on learners any absolute truths which would limit the freedom of their investigation. However, this is a social environment, which should constitute a miniature community, in which individuals can enrich their experience, learn collaboration and prepare for life in democracy.

Such freedom of investigation brings about the risk of reconstruction or even rejection of the rooted ideas and values, yet - it does not mean educational anarchy and is not a sign of naïve romanticism. Just the contrary, it requires social regulations, favourable for the use of an experimental scientific method in deciding about matters important for humanity. (Gutek, 2003, p. 97)

What has a lot of significance in this approach is learners' inner discipline self-discipline and self-control, as owing to this they can prepare for independent and self-disciplined life in the world of adults.

Such type of discipline, oriented to a task or a problem, is precisely shaped during problem solving. In the conditions of acting together and with people, a learner acquires the feeling of control. Instead of controlling the teaching situation, the teacher as a person supporting the didactic process fulfils the function of a guide. (Gutek, 2003, p. 102)

This does not mean that outer discipline cannot appear in the course of school education - yet, it can take place only in the form of indirect helping the learner to find the right tool for solving the cognitive or social problem and in such a way that a learner's activity in class would not generate conflicts and threats for other people acquiring the knowledge and skills in compliance with their interests and needs. In regard to the title of this study, 
it undoubtedly seems indispensable to explain how discipline is currently understood in educational sciences and what alternative school education is. This will allow for noticing the diversity of the aforementioned perspectives of philosophical anthropology in alternative education. It will be also possible to outline the map of paidagogia in alternative schools due to a different approach to disciplining learners, to its exclusion or to its substitution with other pedagogical methods.

What is particularly emphasized in such education is building the school community, as well as shaping citizen, prosocial, allocentric attitudes. In state education, the model of the so-called open schools (die Offene Schule) has appeared - in their curricula, the technocratic rules of management are rejected, along with instrumental evaluation (providing grades), selection and lack of class graduation. "Openness means the ability to notice the essence and the changes in a child's development" (Wallrabenstein, 1992, p. 44). The Jena Plan schools work in a similar way - the process of teaching is directed towards education in the community and through the community. There is no organized space, which in traditional education is created by school classes. Instead, learning takes place in the school living room, which is furnished, equipped and domesticated by learners at various age (Rýdl, 1994). There are no assigned places or desks but applicative furniture and the learning process is a derivative of self-education in mutual co-existence of learners and the teacher. In such an environment, they establish common rules of life and learning. "Each learner has the right to reprimand another, or even the teacher. The care for keeping order and discipline is not a matter of the individual, for instance of the duty person, but of the whole 'clan'. If any conflicts related to this appear in the group, they are treated as pedagogical situations which should be overcome together."(Szymański, 1992, p. 208).

Democracy is associated with control over the means of violence. What increases in the globalizing social order is the role of more radical forms of democratization, also of dialogic democracy. "On one hand, democracy is a tool for representing some interests. On the other, it is a way of building the public scene, where controversial issues can be solved, or at least undertaken, through dialogue and not through earlier settled forms of authority." (Giddens, 2001, pp. 24-25). The world of high social reflectivity leads to increased autonomy of acting, resulting in a variety of changes. Thus, this weakens the bureaucratic authority, which used to be the sine 
qua non of organizational effectiveness, as this authority cannot so easily treat its citizens as "subjects" any longer. More autonomy in the individual's activity allows for their survival and for becoming self-decisive. This is not to be identified with egoism as this autonomy implicates mutuality and co-dependence (Greenberg, 2004, 2006).

What must come into being in such a society is the concern for fracturing the bonds of solidarity, which sometimes might generate selective behaviour or even "re-inventing" tradition. In the society which breaks away from tradition, solidarity is stronger as it is associated with the rebirth of personal and social responsibility for others. This type of solidarity is called by Giddens "active trust" - it does not come from the earlier consolidated social positions or sex-related roles but must be acquired. "Active trust assumes autonomy and does not oppose it, it is a strong source of social solidarity, because such an obligation is undertaken voluntarily, is not imposed by traditional limitations." (Giddens, 2001, pp. 22-23). Trust in other people or institutions needs to be actively worked out and negotiated - therefore, this also concerns the issues called discipline towards the norms binding in a particular society. If the norms established in a particular community, also at school, are not followed, social structures are built on the basis of mutual exchange of goods or services. This means entering the dead end of particularistic benefits, which give birth to the "era of emptiness" or of axiological vacuum.

Democracy, subjectivity and dignity should be cared for by all sides of the educational process in a joint debate, because they will not be ensured by the authoritarian system of imposing obedience. What has been abandoned in postmodern societies is the search for optimal education and all the kinds of interactions among people are subjected to doubt. In postmodern pedagogy, authority is not binding anymore, there is no appealing to obedience, no following the norms or conducting in compliance with some models, no obligation of contracts, no community between the contracting parties. The typical question of the postmodernist breakthrough, asked in the process of investigating the mechanisms of the ruling authorities, would concern the kind of rules and laws used by the authorities in the process of producing the discourse of truth. "The discourse of truth, knowledge, turns out to be not so much the source of authority but its tool, a mechanism of its executing." (Szkudlarek, 1993, p. 39). 


\section{Discipline in the model of self-socialization of children and youth}

Such an approach is applied in the process of self-socialization and selfeducation of children and youth. Teachers are not necessary here and if learners need them in any way, this takes place only at learners' request or demand. This model of education occurs in child republics established by children. Here, they do not have to be guided by the educational standards binding in the state. They can do what they want, without the need for consent from anyone. In the model of self-socialization, they become active subjects of their own developmental changes and they are their competent actors in daily life. Children are not viewed as passive recipients of social and pedagogical influences but as people who have influence on these processes owing to their own activity.

Since the mid-1970s, some ideologies and theories of self-socialization have appeared in humanities which view the child as a complete subject in the process of the own self-development. The creators of self-socialization refer to the new anthropology of the child, according to which what is thought about children determines the theoretical and practical-pedagogical approach to them. Adults' imagined view on a child influences the way in which they treat this child, how they perceive and bring up children and how they behave towards children in daily contacts (Juul, 1999). Perceiving the child as a creature during socialization makes it possible to view and treat children by adults in an open way, which shows respect for differences between them - for their unlikeness. This also allows for noticing that children are able to provide such feedback which will enable regaining lost competences and will help to eradicate ineffective or not accepted behaviour patterns. The self-socializing type of relations generates much more than the contribution to the existence of the dialogue between children and adults. Owing to this, everyone can find their own way to the goal, although it will be equally suitable for everyone, nor will it belong to the "anything goes" model.

What becomes the major principle here is creating by everyone, for themselves and for all others altogether, the same criteria which will allow for the evaluation of behaviours and their consequences.

Today, it is a much better-known fact that children are competent in the following scope: 
- they can indicate the contents and limits of their integrity;

- from birth, they are social beings, they collaborate competently if they face (on the part of adults) the same form of conduct, regardless of its constructive or destructive impact on their life;

- they provide parents with verbal and non-verbal feedback information, which also constitutes competent hints concerning emotional and existential problems of their own parents.

History has already proved that children can create a community in which an autonomic education system will appear. Children themselves create their living environment, which is isolated from adult domination. This principle also pertains to the environments in which it is not adults who educate children, but children are educating children. Such a model takes place in surroundings such as large families, where a specific sub-community comes into being - it functions within the family model but in a milder form, in which the elder brothers and sisters bring up the younger siblings. What takes place in such a family is the reduced pressure of authority, the right to protest and the practice of mutual advising or help. This model has its forerunners in history. In 1917 in Nebraska, Edward Joseph Flanagan, an American priest, founded a centre for children, which later moved to the country, to a deserted farm west of Omaha. They built several houses there and called their farm "Boys Town". It resembled a village in which children and youth established the board out of their own inhabitants and chose the village council, managing it autonomously.

This community was the model for the child republics which came into being in Spain, Columbia, Brazil, etc. One of them was established in 1956 for 15 children by Father Jesus Silva Mendez. Soon, children from all over the world were coming there. Within a few years, the small children community in the town of Bemposta was transformed into a child town, and later a children republic, in the north of Galicia (where over one thousand children lived until the late 1970s). This republic, joint by the town of Celanova (in which a camp at the Atlantic seaside was founded), had their own school system, legal system, their own authorities and industry. Adults did not have any rights to decide about children's life (Szymański, 2016). The model of learning which excludes obligation and violence has its modern counterparts - the idea of Ivan Illich's deschooling society or the anarchist approach to school education 
(Illich, 1976, 2001). Here, learning has the purely individual character if the person feels such a need at all and wants to learn. This approach is offered in free schools, which were established worldwide in the 1960s.

\section{Conclusion}

Teachers' approaches to moral education at school as well as the approach of the creators of alternative schools are not always determined by particular philosophical anthropology. Their diversity also frequently results from religious, ideological, psychological or social preferences, the essence and scope of which are often implicit. Therefore, the background in which alternative schools come into being is diversified. Some constitute the continuation, reproduction or imitation of more or less orthodox premises of pedagogy which had their origin in the early 20th century, the others seek unlikeness, originality or eclectic solutions which adjust the educational offer to the changing conditions of everyday life. Teachers who reach for a certain educational philosophy, ideology or theory become "rulers" armed with it have accepted part of the power and causative force over their learners. Therefore, what waits for them is the task of reading, classifying and comparing this multitude of theories, so that they could see, owing to them, this particular play of various layers and shades of ideas, thoughts or values. So far, this has occurred unnoticed, as they have been closed in the system of earlier assumptions, quite different from the ones promoted in these theories.

Every educationalist should know, understand and compare the different cognitive perspectives (present in educational sciences), which describe the essence of education, explain its phenomenon and specify the particular role of the teacher in many different ways. It is not enough to reach for a theory, it should be used in such a way so that not only educators could feel well with it but, first of all, those whom this selected theoretical perspective concerns learners. Even when one theory informs about something and another tells the same, they are not the same. In the postmodern world, full of many varieties of thinking about education and of many practical solutions which are already rooted in compliance with these varieties, the educationalist can adopt the attitude of a wanderer, who moves along the track and uses an adequate map of the pluralistic world of pedagogical thoughts and theories, before choosing or constructing the own concept of education. 
Knowledge of alternative education is necessary for teachers in this sense that, as a result of global communication, they recognize and experience a contradiction between the abundance of constantly generated ideas, approaches, orientations in the field of school education and the impossibility to apply them in practice. An educationalist makes a choice from various territories of knowledge - such which can fulfil the role of "home" and those in which one is as if "on one's own". Owing to this roaming, teachers realize how far they have gone from their "home", from the pedagogy learned during university studies and in the course of preparing for the teacher's role, when they enter uncharted territory (Rewers, 1995, p. 45). Thus, it is worth enter such a decentred and chaotic pedagogical reality in order to, being conscious of its contexts, find space for reflection upon education and the place of discipline in it or its elimination from school practice.

The knowledge of these issues cannot be accumulated or given one common all-embracing label, because "[...] each theory, to a certain extent, can describe the world. The social world is not ontologically monolithic: it is diversified, complicated, internally contradictory, dynamic, constantly open, unceasingly in the process of becoming." (Melosik, 1995, p. 20). Among educators, there are those who are aware which knowledge is necessary or useful for them in a particular period. Depending on whether they are reflective practitioners or experimenters searching for answers to questions, in compliance with J. Dewey's idea, they crave for knowledge - not only from the philosophical, but also pedagogical, sociological, psychological or ideological perspective. Those who seek solutions not having previously defined the sources of didactic justification of their implementation apply the pedagogy understood in this way in order to choose (while wandering through the world of different ideas and their theoretical justifications) the most appropriate pedagogy for them - to "consume" it in their own practice or theory of education.

Contemporary knowledge concerning education does not provide all teachers with the feeling of certainty, peace, freedom from doubts as a result of recognizing new or rediscovering "old" theories and models of education. They might be in a new (e.g. linguistic, visual) wrapping, but still:

[...] every theory refers as if to a slightly different world, to a particular historical moment and to its particular understanding. [...] The world consists of many equitable and contradicting, dispersed realities, which EXIST simultaneously. 
One can be in several "at the same time". Thus, after a while of thinking in one convention, one can think the world in another, taking into brackets the result of the previous intellectual work. If we accept this, we will not tend to deny (which is modern in its essence) the existence of such realities and theories that do not stem from our own biography and experience. (Melosik, 1995, p. 20)

Educators face the dilemma of whether - in the light of social, democratizing changes and the related processes of rapid and universal communication education towards and in discipline should not be replaced by education in active trust, in experiencing the value and reliability of norms which ought to be understandable, accepted and received as individual and the collective at the same time (by both teachers and their learners). Does the school which uses coercion and discipline not multiply problems itself? (Mieszalski, 1997). What currently seems to be relevant is Z. Bauman's thesis (Szkołut, 1999) that, in the course of education directed towards following social norms, autonomous morality should be prioritized, which knows only one obligation - to take care of and respect the Other, the care and respect that do not claim any reciprocity as the moral relation is basically asymmetrical. Thus, the school faces ever more difficult, and perhaps more ambitious challenges.

transl. by Agata Cienciała

\section{References}

Bauman, Z. (1996). Etyka ponowoczesna. Warszawa: Wydawnictwo Naukowe PWN.

Bendl, S. (1998). Strašidlo nekázně aneb hledání východiska ze školských labyrintů. Praha: TH.

Bendl, S. (2001). Školní kázeň. Metody a strategie. Praha: ISV.

Bendl, S. (2003). Prevence a řešení šikany ve škole. Praha: ISV.

Bendl, S. (2004a). Kázeňské problemy ve škole. Praha: Triton.

Bendl, S. (2004b). Neukázněny žák. Cesta instituionální pomoci. Praha: ISV.

Bendl S., (2004c). Jak předcházet nekázni aneb kazeňské prostředky. Praha: ISV nakladatelství.

Bendl, S. (2005). Ukázněna tř́da aneb Kázeňské minimum pro učitele. Praha: Triton.

van Dick, L. (1979). Alternativschulen. Information-Probleme-Erfahrungren. München: Rowohlt Taschenbuch Verlag GmbH.

Dietrich, T. (1995). Die Pädagogik Peter Petersen. Der Jena Plan: Beispiel einer humanen Schule. Bad Heilbrunn: Klinkhardt.

Dziewiecki, M. (2006). Co dalej z wychowaniem $w$ szkole? Retrieved from http://www. naszdziennik.pl/index.php?typ=my\&dat $=20061114 \& i d=$ my11.txt

Edwards, C. H. (2006). Dyscyplina i kierowanie klasq. Warszawa: WN PWN. 
Fish, S. (2006). Złodzieje języka, Gazeta Wyborcza z dnia 22-23 lipca.

Freinet, E. (1991). Erziehung ohne Zwang. Der Weg Célestin Freinets. München: DTV Verlag GmbH\&Co.KG.

Freire, P. (1973). Pedagogy of the Oppressed. Nex York: Seabury.

Giddens, A. (2001). Poza lewicq i prawicą. Przyszłość polityki radykalnej. Poznań: Zysk i S-ka.

Gordon, T. (1991). Wychowanie bez porażek. Rozwiq̨zywanie konfliktów między rodzicami a dziećmi. Warszawa: IW PAX.

Gordon, T. (1995). Wychowanie bez porażek w szkole. Warszawa: IW PAX.

Gordon, T. (1997). Wychowanie w samodyscyplinie. Warszawa: IW PAX.

Greenberg, D. (2004). Endlich frei! Leben und Lernen an der Sudbury - Valley - Schule. Freiamt im Schwarzwald: Arbor Verlag.

Greenberg, D. (2006). Ein klarer Blick. Neue Erkenntnisse aus 30 Jahren Sudbury Valle School. Leipzig: Tologo Verlag.

Gutek, G. L. (2003). Filozoficzne i ideologiczne podstawy edukacji (Philosophical and Ideological Perspectives on Education). Gdańsk: GWP.

Illich, I. (1976). Społeczeństwo bez szkoły. Warszawa: PIW.

Illich, I. (2001). Odškolnění společnosti. Praha: SLON.

Juul J. (1999). Das kompetente Kind. Reinbek be Hamburg: Rowohlt.

Key, E. (2005). Stulecie dziecka. Warszawa: Akademickie „ŻAK”.

Kohl, H. R. (1971). Antiautoritärer unterricht in der Schule von heute. Erfahrungsbericht und praktische Anleitung. Reinbek bei Hamburg: Rowohlt Verlag GmbH.

Korczak, J. (1984). Pisma wybrane. Warszawa: Nasza Księgarnia.

Kosiorek, M. (2007). Pedagogika autorytarna. Geneza, modele, przemiany. Kraków: Oficyna Wydawnicza „Impuls”.

Ludwig, P. (Ed.). (1997). Summerhill: Antiautoritäre Pädagogik heute. Ist die frei Erziehung tatsächlich gescheitert? Weinheim: Beltz Verlag.

Melosik, Z. (1995). Postmodernistyczne kontrowersje wokół edukacji. Toruń - Poznań: Edytor, s.c.

Mieszalski, S. (1997). O przymusie i dyscyplinie w klasie szkolnej. Warszawa: WsiP.

Miller, A. (1991). Mury milczenia. Cena wyparcia urazów dzieciństwa. Warszawa: PWN.

Miller, A. (1995). Dramat udanego dziecka. Studia nad powrotem do prawdziwego. Warszawa: J. Santorski.

Miller, A. (1999). Zniewolone dzieciństwo. Ukryte źródła tyranii. Poznań: Media Rodzina.

Miller, A. (2000). Ścieżki życia. Historie, w których każdy odnaleźć może własne losy. Poznań: Media Rodzina.

Miller, A. (2006a). Gdy runq mury milczenia. Prawda faktów. Poznań: Media Rodzina.

Miller, A. (2006b). Bunt ciała. Poznań: Media Rodzina.

Montessori, M. (1990). Kinder sind anders. München: U. Weber, dtv/Klett-Cotta.

Montessori, M., Oswald, P., \& Schulz-Benesch, G. (1976). Schule des Kindes. Montessori-Erziehung in der Grundschule. Freiburg: Verlag Herder.

Muszyńska, E. (1997). Swoboda, przymus i przemoc w relacjach: dziecko-dorosły. Poznań: UAM w Poznaniu.

Nawroczyński, B. (1987). Przymuszać czy wyzwalać? Dzieła wybrane. Warszawa: Wybór, przedmowa i wstęp Anna Mońka-Stanikowa, WSiP. 
Neill, S. A. (1969). Theorie und Praxis der antiautoritären Erziehung. Das Beispiel Summerhill. Reinbek bei Hamburg: Rowohlt.

Neill, A. S. (Ed.). (1975). Die Befreiung des Kindes. Frankfurt am Mein: Fischer Taschenbuch Verlag.

Popp, S. (1995). Der Daltonplan in Theorie und Praxis. Ein aktuelles reformpädagogisches Modell zur Förderung selbstständigen Lernens in der Sekundarstufe. Bad Heilbrun: Verlag Justus Klinkhardt.

Pyżalski, J. (2007). Nauczyciele-uczniowie. Dwa spojrzenia na dyscyplinę w klasie. Kraków: „Impuls“.

Röhner, R., Wenke, H. (2003). Daltonské vyučování. Stále živá inspirace. Brno: Paido.

Rewers, E. (1995). Koniec podróży. Trudna ponowoczesność. Poznań: Fundacji Humaniora.

Robertson, J. (1998). Jak zapewnić dyscyplinę, ład i uwagę w klasie. Warszawa: WSiP.

Rýdl, K. (1994). Alternativní pedagogické hnutí v současné společnosti. Brno: Marek Zeman.

Rýdl, K. (2001). Peter Petersen a pedagogika jenského planu. Praha: ISV.

Selye, H. (1974). Stres okiełznany. Warszawa: PIW.

Sławiński, S. (1994). Spór o wychowanie w posłuszeństwie. Warszawa: IW PAX.

Surzykiewicz, J. (2000). Agresja i przemoc w szkole. Warszawa: Centrum Pomocy PsychologicznoPedagogicznej.

Štrynclová, G. (2003). Summerhill. Model antiautoritativní výchovy. Pardubice: Univerzita Pardubice, Fakulta humanitních studií.

Szkołut T. (1999). Awangarda, neoawangarda, postawangarda. Lublin: Wydawnictwo UMCS.

Szkudlarek, T. (1993). Wiedza i wolność w pedagogice amerykańskiego postmodernizmu. Kraków: Oficyna Wydawnicza Impuls.

Szymański, M. S. (1992). Niemiecka pedagogika reformy 1890-1933. Warszawa: WSiP.

Szymański, M. S. (2016). Myślenie i działanie w Drugiej Rzeczypospolitej. Esej politycznooświatowy. Warszawa: Wydawnictwo Akademickie „Żak”.

Śliwerski, B. (1996). Klinika szkolnej demokracji. Kraków: „Impuls”.

Śliwerski, B. (1998). Współczesne teorie i nurty wychowania. Kraków: Oficyna Wydawnicza „Impuls”.

Śliwerski, B. (2009). Problemy współczesnej edukacji. Dekonstrukcja polityki oświatowej III RP. Warszawa: WAiP.

Thurn, S., Tillman, K. J. (1997). Unsere Schule ist ein Haus des Lernens. Das Beispiel Laborschule Bielefeld. Reinbek bei Hamburg: Rowohlt Taschenbuch Verlag GmbH.

Wallrabenstein, W. (1992). Offene Schule-Offener Unterricht. Raatgeber füt Eltern und Lehrer. Reinbek bei Hamburg: Rowohlt Taschenbuch Verlag.

Witkowski, L. (2009). Pięć lat późnie. Szkoła polska: między barbarzyństwem i Europq (lekcja „toruńska” i ślady prasowe - pięć lat później i co dalej?). Toruń: Wydawnictwo Adam Marszałek.

Zarzour, K. (2006). Gnębiciel ze szkolnego boiska. Jak radzić sobie z dziecięcq agresjq̨ i wychować asertywne dziecko. Poznań: Dom Wydawniczy REBIS. 


\title{
Author
}

Prof. dr hab. Bogusław Śliwerski dr h.c. multi, University of Łódź, Faculty of Education, Department of Theory of Education, Pomorska 46/48, 91-408 Łódź, e-mail: boguslaw.sliwerski@uni.lodz.pl

\section{Kázeň ve světle alternativních způsobů vzdělávání}

\begin{abstract}
Abstrakt: Studie představuje analýzu konceptu kázně v alternativních školách ve světě. $\mathrm{V}$ rámci pedagogiky se dlouhodobě diskutuje problém role a místa kázně ve školním vzdělávání, jelikož existuje mnoho nedorozumění, protikladů a mýtů s tímto tématem spojených. Tento problém je většinou pojednáván fragmentárně nebo jednostranně podle toho, kdo je zastáncem jaká ideologie vzdělávání, tedy zda je proponent odpůrcem nebo zastáncem ukázňování žáků ve škole. Předkládaná studie se věnuje otázce, zda existuje rozdíl mezi názory a př́stupy ve státních a alternativních školách. Navrhuji soustředit se na modely (ne)kázně ve škole podle toho, zda ji učitelé akceptují nebo ji naopak postrádají. Z předložených úvah na závěr dovozuji, že v dnešním globálním světě propojených významů, teorií, modelů, zkušeností a jednotlivých řešení nejsou alternativní školy př́liš odlišné od některých škol státních.
\end{abstract}

Klíčová slova: alternativní vzdělávání, pedagogika, škola, kázeň, ideologie vzdělávání, svoboda a př́sná výchova 